Glasgow, where he was trained as an anatomist by Prof. John Cleland, whose senior medallist and junior demonstrator he was. He graduated with honours M.B., Ch.B. in 1907 and was Brunton Memorialist of his year. After a year in private practice he became senior assistant to Prof. T. H. Bryce in his old University. In 1915 he received the Bellahouston and Struthers gold medals for his M.D. thesis on "The Scottish Skull", and was in the same year appointed by the Medical Research Council to work under the late Dr. John Brownlee on the stupendous task of compiling and analysing a case record and card-index of all officers and men admitted to hospital during the War of 1914-18. This work, which was not completed until 1922, involved the preparation and arrangement of $\mathbf{2 2}$ million index cards and the analysis of a million and a quarter medical case sheets. This material was taken over by the Ministry of Pensions.

Young continued on the staff of the Medical Research Council until 1927, when on the death of Dr. Brownlee and after taking the D.P.H. of Cambridge, he was transferred to the external staff and by a special arrangement was attached to Elliot Smith's department at University College, London, holding the position of lecturer in anatomy. This was perhaps the happiest and most fruitful period of his life. It gave him the opportunity he had long desired, to return to his studies in anatomy and anthropology, as well as of exercising his powers of statistical analysis, of which he had first given assured evidence in his thesis on the Scottish skulls, and had further demonstrated in statistical papers, some twenty in number, published during 1920-27 and including studies in epidemiology and the incidence and mortality of cancer. It has been said that Young's work substantially raised the standard of medical research in Great Britain by insisting on the proper biometrical treatment and interpretation of numerical data. Further, his work at University College in congenial surroundings gave full scope to those sound, if unobtrusive qualities, of which the most highly valued was his constant readiness to place his abilities and his profound knowledge at the service of colleagues and students alike. $\mathrm{He}$ was invited to join the committees of the Medical Research Council on dental disease and statistics. In connexion with the work of the former he published a study of the relation of dietary deficiency to dental disease, dealing. with data collected in Birmingham under the auspices of the committees.

As anatomist and anthropologist, Young published numerous papers, perhaps half in collaboration with others ; and it is no exaggeration to say that several of these of considerable value would never have been written had it not been for his encouragement and readily offered assistance. $\mathrm{He}$ was particularly interested in the problems of facial growth with reference to the development of dentition. One of his most important contributions to the subject was a study of the growth of face and jaws in children, which with other work gained him the D.Sc. of the University of Edinburgh. More directly anthro- pological studies were his collaboration with Sir Grafton Elliot Smith in the study of the London skull known as "The Lady of Lloyd's".

\section{Mr. H. Higgs}

Henry Higgs, who died on May 21, belonged to that type of economist of which John Stuart Mill was the leading example in an earlier generation, the economist public servant. Born in 1864, he entered the Post Office secretariat in 1884 ; was transferred to the Treasury fifteen years later; and served as private secretary to a succession of statesmen. $\mathrm{He}$ retired from the Treasury in 1921; was for a time lecturer in economics at Bangor and, for the ten years, 1929-39, was occupied mainly with work on the "Economic Bibliography", of which a first volume appeared in 1935.

While at the Treasury, Mr. Higgs was the first secretary of the Royal Economic Society and joint editor of the Economic Journal from 1892 until 1906. $\mathrm{He}$ had special knowledge of the thinkers of the eighteenth century; and his work on Cantillon and the Physiocrats was of a high order. His position at the Treasury enabled him to write with authority on questions of public finance. But, as his editing of Jevons's "Principles of Economics" (1905) and his repeated tenure of the Newmarch lectureship in statistics show, there was no aspect of economic thought with which he was not in contact.

Besides, Higgs had served as Inspector General of Finance in Egypt (1912-15) and had done other specialist work for the State. This made the range of his scholarship the more remarkable and explains the fact that, in spite of it, his learned output was rather fragmentary-the product of the hardly secured leisure of a very busy man. Some of the editorial work with which he was engaged after his retirement from public and academic activity was not of the kind to bring him much added reputation, and not all of it was equal to the work of his prime. In these last years he was, however, handicapped by failing health and almost complete deafness, which isolated him somewhat from colleagues and friends.

WE regret to announce the following deaths:

Prof. W. F. Bork, emeritus professor of psychology in Indiana University, on May 22, aged sixty-six years.

Prof. A. Fowler, C.B.E., F.R.S., emeritus professor of astrophysics in the Imperial College of Science and Technology and in the University of London, and formerly Yarrow research professor of the Royal Society, on June 24, aged seventy-two.

Dr. Phyllis Tookey Kerridge, formerly lecturer in physiology, University College, London, on June 22. Dr. Alvin S. Wheeler, emeritus professor of organic chemistry in the University of North Carolina, on May 12, aged seventy-three.

Prof. F. J. E. Woodbridge, emeritus Johnsonian professor of philosophy in Columbia University, on June 1, aged seventy-three. 